\title{
Detection of messenger RNA using a digoxigenin end labelled oligodeoxynucleotide probe
}

\author{
M Farquharson, R Harvie, A M McNicol
}

\begin{abstract}
A synthetic oligodeoxynucleotide sequence complementary to the mRNA for the adrenocorticotrophin (ACTH) precursor pro-opiomelanocortin (POMC) was end labelled using digoxigenin. The probe was used to detect POMC mRNA both on nitrocellulose filters and by non-isotopic in situ hybridisation (NISH) in tissue sections. Digoxigenin was identified using anti-digoxigenin alkaline phosphatase. The model system examined was the rat pituitary gland. Removal of both adrenal glands and dexamethasone administration were used to change the concentrations of POMC MRNA in the rat anterior lobe. The labelled probe reacted with a single band of appropriate molecular weight in Northern blot analysis. The distribution of signal in tissue sections and the changes induced by experimental manipulation were as predicted.
\end{abstract}

The results indicate that this method of NISH will prove useful in the detection of specific messenger RNAs in tissue sections of buffered, formalin fixed, paraffin wax embedded material.

In situ hybridisation has been used increasingly to localise specific messenger RNAs (mRNAs) in tissue sections, the initial studies using mainly double stranded complementary DNA (cDNA) probes ${ }^{12}$ and, more recently, complementary RNA (cRNA) sequences. $^{34}$ Radioactive labelling produces probes of high specific activity, and autoradiography was the method of choice for localisation in early experimental studies. These methods have disadvantages for routine laboratory use and considerable effort, therefore, is being directed towards the development of non-isotopic labelling systems which can readily be applied in diagnostic laboratories. To date, success has been achieved mainly with biotin labelling, followed by binding of an avidin-enzyme complex detection system, ${ }^{5-7}$ but such labelling techniques may pose problems in tissues with high concentrations of endogenous biotin, such as liver and kidney.

An alternative non-radioactive labelling method uses digoxigenin, a derivative of the cardiac glycoside digoxin which can be identified by immunohistochemical techniques. As digoxigenin-11-dUTP it has been incorporated into $\mathrm{cDNA}$ probes by nick translation and random priming to detect DNA sequences in filters ${ }^{8}$ and, more recently, in tissue sections. ${ }^{9}$ Its use in the detection of mRNAs has not so far been reported.

With the advent of DNA synthesisers, attention has turned to the use of short single stranded oligodeoxynucleotide probes (oligomers). These are easily synthesised and have the advantage of better penetration of tissue sections than the larger probes. $^{10}$ Oligomer probes of high specific activity have been produced by labelling at the $3^{\prime}$ end with radioactive or biotinylated nucleotides, using terminal deoxynucleotidyl transferase, but, again, the use of digoxigenin for end labelling has not been reported.

In this study we describe the use of a digoxigenin end labelled oligomer in the localisation of mRNA in both Northern blot and tissue sections. We used a model system in which concentrations of specific mRNA can be manipulated in the detection of mRNA for the adrenocorticotrophin (ACTH) precursor pro-opiomelanocortin (POMC) in the rat pituitary gland. The probe sequence has been reported previously in a study of biotin labelling. ${ }^{11}$

\footnotetext{
University Pathology, Royal Infirmary, Castle Street, Glasgow G4 0SF

M Farquharson R Harvie A $\mathrm{M} \mathrm{McNicol}$

Correspondence to: Dr A M McNicol

Accepted for publication 6 December 1989
}

\section{Methods}

Adult male Sprague Dawley rats (weighing 250-350 g) were used. They were maintained in a heat $\left(21^{\circ} \mathrm{C}\right)$ and light $(0800-2000$ hours) controlled environment. Food and water were freely available. Groups $(n=4)$ underwent the following experimental procedures: bilateral removal of the adrenal glands or "sham operation," killed after 14 days; dexamethasone administration $(200 \mu \mathrm{g} / \mathrm{kg}$ body weight) by daily intraperitoneal injection for 10 days. All animals were killed by cervical dislocation. Pituitary glands were removed from intact and experimental animals and immersion fixed in $4 \%$ paraformaldehyde or $10^{\circ}{ }_{0}$ neutral buffered formalin for 18 hours. Tissues were processed to paraffin wax and $4 \mu \mathrm{m}$ sections were cut on to glass slides coated with aminopropyltriethoxysilane. ${ }^{12}$

A 24-mer sequence was synthesised using the $\beta$-cyanoethyl phosphoramidite method on an Applied Biosystems Automated DNA Synthesiser- $5^{\prime} \mathrm{d}$ (CTT GCC CCA GCG GAA GTG CTC CAT) 3'. This sequence is complementary to the region of POMC mRNA coding for the adrenocorticotrophin (ACTH) 4-11 sequence. ${ }^{11}$ 
LABELLING

The probe was labelled at the $3^{\prime}$ end using terminal deoxynucleotidyl transferase. The reaction was cariied out as follows: to tailing buffer (BRL: $100 \mathrm{mM}$ potassium cacodylate, pH7.2, $2 \mathrm{mM} \mathrm{CoCl}_{2}, 0.2 \mathrm{mM}$ DTT) was added $1 \mu \mathrm{g}$ of POMC probe, $5 \mathrm{nmol}$ digoxigenin-11-dUTP (Boehringer Mannheim) or 5 nmol biotin-16-dUTP (Boehringer Mannheim), 2 nmol unlabelled dCTP (Pharmacia) and 30 units terminal deoxynucleotidyl transferase (BRL). The volume was made up to $50 \mu \mathrm{l}$ with water. The reaction mixture was incubated at $37^{\circ} \mathrm{C}$ for one to 18 hours and stopped by the addition of $5 \mu \mathrm{l} 100 \mathrm{mM}$ EDTA. Labelled probe was separated from unincorporated material using a G25 Sephadex column (Pharmacia). Ten $200 \mu \mathrm{l}$ fractions were collected, $1 \mu \mathrm{l}$ of each spotted on to pre-wetted nitrocellulose and the filters baked for two hours at $80^{\circ} \mathrm{C}$. Digoxigenin labelled probe was detected following the manufacturer's instructions and biotin labelled probe by a streptavidin-biotin alkaline phosphatase system (Gibco BRL). Those fractions containing labelled probe were pooled and lyophilised.

\section{IN SITU HYBRIDISATION}

Sections were dewaxed in two changes each of xylene, industrial alcohol, and methylated spirits and then rinsed in phosphate buffered saline (PBS). The hydrated sections were given the following pretreatments: sections were placed sequentially in $0.2 \mathrm{~N} \mathrm{HC1}$ for $20 \mathrm{~min}$ utes, $0 \cdot 3^{\circ}{ }_{0}$ Triton X-100 (Sigma) in PBS for 15 minutes, $0-20 \mu \mathrm{g} / \mathrm{ml}$ proteinase $\mathrm{K}$ (Sigma) in $0 \cdot 1 \mathrm{M} / \mathrm{TRIS}$ buffer (pH8), $50 \mathrm{mM}$ EDTA for 30 minutes at $37^{\circ} \mathrm{C}$ and $0 \cdot 2 \%$ glycine for one minute. They were post-fixed in $4 \%$ paraformaldehyde for five minutes, then finally in $0.25^{\circ}{ }_{0}$ acetic anhydride in $0.1 \mathrm{M}$ triethanolamine $(\mathrm{pH} \mathrm{7.5)}$ for 10 minutes. The slides were rinsed in PBS between each pretreatment and all procedures were carried out at room temperatures unless otherwise stated. Sections were placed in prehybridisation buffer $(50 \%$ formamide $/ 2 \times$ SSC $) \quad(1 \times$ SSC $=0.15 \mathrm{M}$ sodium chloride, $0.015 \mathrm{M}$ sodium citrate) for two hours at $37^{\circ} \mathrm{C}$. Twenty $\mu \mathrm{l}$ of hybridisation buffer containing $0 \cdot 5-100 \mathrm{ng}$ POMC probe was applied to the appropriate section. Hybridisation buffer consisted of $0.01 \mathrm{M}$ TRIS (pH 7.5), $12.5 \%$ Denhardt's solution $\left(0.02^{\circ}{ }_{0}\right.$ Ficoll 400 (Sigma), $0.02 \%$ bovine serum albumin, $0.02 \%$ polyvinylpyrrolidone) $2 \times$ SSC, $30-50 \%$ formamide, $0.5 \%$ sodium dodecyl sulphate, $250 \mu \mathrm{g} / \mathrm{ml}$ salmon sperm DNA (Sigma) and $5 \mathrm{mg} / \mathrm{ml}$ sodium pyrophosphate. The sections were covered with dimethyldichlorosilane coated coverslips and hybridisation was carried out in a sealed humid box at $42^{\circ} \mathrm{C}$ for 18 hours. Coverslips were removed in $4 \times$ SCC and sections washed. The post-hybridisation washes were: two changes of $2 \times$ SSC, 10 minutes each at room temperature, then two changes of $0.1 \times$ SSC, 20 minutes each at $42^{\circ} \mathrm{C}$, followed by one change of $0 \cdot 1 \times \mathrm{SSC}$ at room temperature.
BIOTIN DETECTION STEP

Slides were washed once in $0 \cdot 1^{\circ}$ Triton X-100 in modified TRIS buffered saline (TBS: $0.05 \mathrm{M}$ TRIS, $0.15 \mathrm{M}$ sodium chloride, $2 \mathrm{mM}$ magnesium chloride hexahydrate, $0.1 \%$ bovine serum albumin, pH 7.6). Alkaline phosphatase conjugated streptavidin (Gibco BRL or Boehringer Mannheim) was applied at $1 / 500-1 / 8000$ for 30 minutes followed by two five minute washes in TBS then one in buffer $3(0.1 \mathrm{M}$ TRIS $\mathrm{HCl}, 0.1 \mathrm{M}$ sodium chloride, $0.05 \mathrm{M}$ magnesium chloride hexahydrate, pH 9.5). Binding was visualised using nitroblue tetrazolium dye solution as substrate.

\section{DIGOXIGENIN DETECTION STEP}

Before detection, sections were washed once for five minutes in buffer $1(0.1 \mathrm{M}$ TRIS HC1, $0 \cdot 15 \mathrm{M}$ sodium chloride, $\mathrm{pH} 7 \cdot 5)$. Alkaline phosphatase conjugated sheep anti-digoxigenin (Boehringer Mannheim) was applied at 1/500-1/5000 for two hours at room temperature. Unbound conjugate was removed by washing in two changes of buffer 1 ( 15 minutes each) followed by one wash in buffer 3 . The reaction was visualised as above. Incubation time in dye ranged from two to 18 hours after which slides were rinsed in distilled water, counterstained with neutral red, and mounted using Glycergel aqueous mounting medium (Dako).

The following controls were performed:

1 Sections were processed as described above but in the absence of labelled probe.

2 Sections were subjected to RNAse A (Boehringer Mannheim) treatment $(100 \mu \mathrm{g} /$ $\mathrm{ml}-200 \mu \mathrm{g} / \mathrm{ml}$ in $2 \times \mathrm{SSC}$ for two hours at $37^{\circ} \mathrm{C}$ ) before hybridisation. RNAse was heated at $100^{\circ} \mathrm{C}$ for 10 minutes, then allowed to cool to room temperature before use, to abolish residual DNAse activity.

3 An initial hybridisation was carried out with unlabelled probe in excess followed by incubation with labelled probe.

\section{NORTHERN BLOT ANALYSIS}

RNA was extracted from rat pituitaries using RNAzol (Biogenesis Ltd) and separated on a $1 \cdot 2^{\circ}{ }_{0}$ agarose/formaldehyde gel. The RNA was transferred overnight to a nitrocellulose filter using $20 \times$ SSC after which the filter was baked at $80^{\circ} \mathrm{C}$ for two hours. The filter was hybridised overnight with $50 \mathrm{ng}$ probe $/ \mathrm{ml}$ buffer at $42^{\circ} \mathrm{C}$. The post-hybridisation washes were two 15 minute washes each of $2 \times \mathrm{SSC} /$ $0.2 \%$ SDS, $0.2 \times$ SSC $/ 0.1 \%$ SDS, $0.1 \times$ SSC $/ 0 \cdot 1 \%$ SDS. Detection of the biotinylated probe was carried out essentially as described previously ${ }^{11}$ and the procedure for the digoxigenin labelled probe as above.

\section{Results}

NORTHERN BLOT ANALYSIS

A single band was seen when the blot was hybridised with the biotinylated POMC probe (fig 1), representing a single mRNA species of around 1400 bases. An identical band was visualised using digoxigenin labelled probe but the filter required a longer incubation in dye 
Figure 1 Northern blot analysis. Biotin labelled oligodeoxynucleotide probe complementary to POMC $m R N A$. A single $m R N A$ band of around 1400 bases is identified. The positions of ribosomal RNAs run on the same gel are shown.

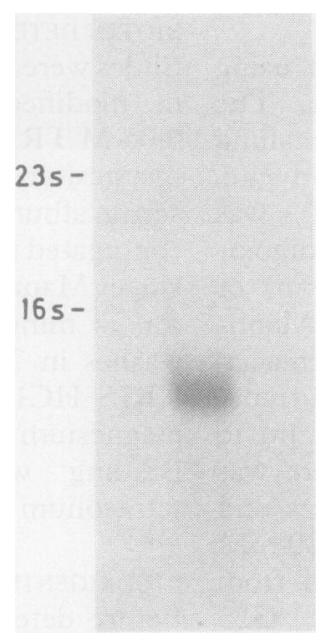

substrate. This resulted in increased background.

\section{IN SITU HYBRIDISATION}

Normal animals

Results were best with 1/500 dilution of antidigoxigenin antibody. Digoxigenin labelled probe hybridised to all cells in the intermediate lobe, and to a population of cells in the anterior lobe (fig 2). These had the character stellate appearance of corticotrophs. In the absence of proteinase $\mathrm{K}$ only a weak intermediate lobe signal was identified. In the presence of $10 \mu \mathrm{g} /$ $\mathrm{ml}$ proteinase $\mathrm{K}$ a reproducible strong signal was seen in both anterior and intermediate lobes, without any noticeably deleterious effect on morphology. Labelling was seen in both paraformaldehyde and buffered formalin fixed tissues with no subjective difference noted between the two.

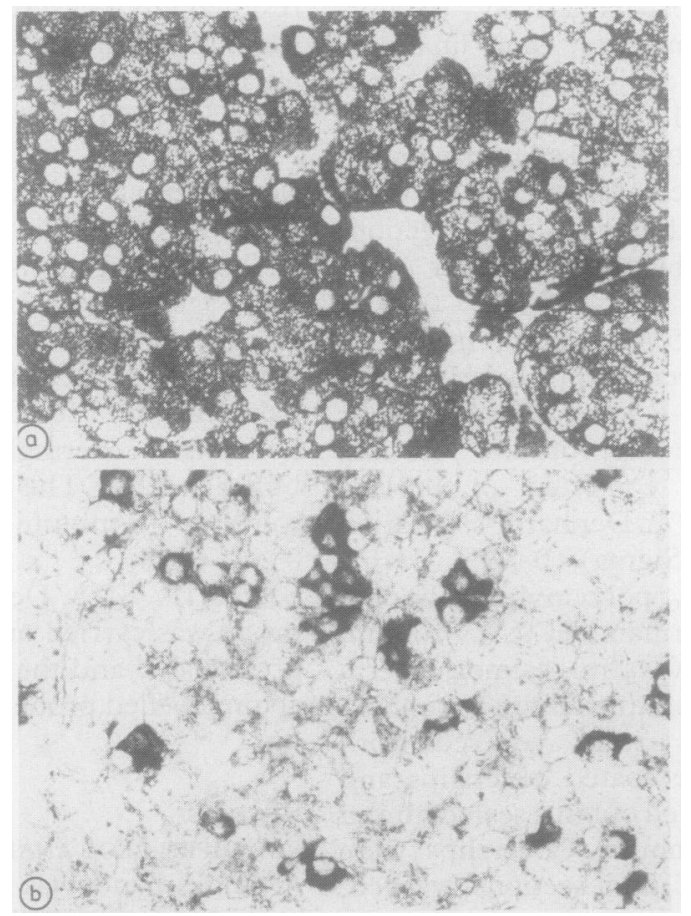

Figure 2 In situ hybridisation of rat pituitary gland with POMC oligoprobe, end labelled with digoxigenin. Positive signal is seen in all the cells of the intermediate lobe (a) and in a population of stellate cells within the anterior lobe $(b)$.
Biotin labelled probe also gave a positive signal, but was associated with a high background. This was seen with both streptavidin alkaline phosphatase conjugates tested. This rendered it less useful in identifying individual positive cells.

No specific signal was obtained in the absence of probe. Staining was abolished by treatment with RNAse (fig 3). Preincubation with unlabelled probe considerably reduced intermediate lobe staining and abolished the anterior lobe signal.

\section{Experimental manipulation}

Only digoxigenin labelled probe was assessed in these studies. Bilateral removal of adrenals resulted in an increase in the number of positive cells in the anterior lobe (fig 4) and the signal was subjectively stronger. Staining could be abolished as in the normal glands. Dexamethasone treatment produced no decrease in the subjective intensity of the intermediate lobe signal, but a very obvious decrease in the anterior lobe (fig 5), with only scattered individual cells giving a weak signal.

\section{Discussion}

We have shown that $3^{\prime}$ end labelling with digoxigenin is effective in producing oligonucleotide probes for the detection of specific mRNA both in tissue sections and in Northern blot analysis. The probe used is complementary to the sequence of POMC mRNA coding for ACTH 4-11, and hybridisation studies with tritiated thymidine and biotin labelling have previously been reported. ${ }^{113}$ The distribution of signal corresponded to that of POMC peptides and mRNA in the rat

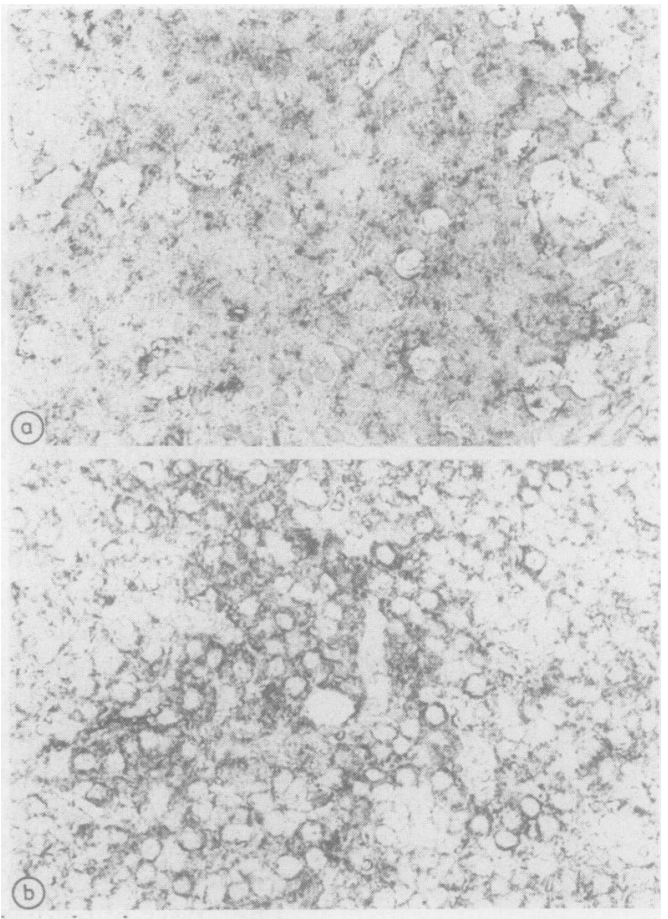

Figure 3 In situ hybridisation performed after pretreatment with RNAse. The signal is abolished both in intermediate ( $a$ ) and anterior (b) lobes. 
Figure 4 There is an increase in the number of cells with positive signal in the anterior lobe after bilateral removal of adrenals.

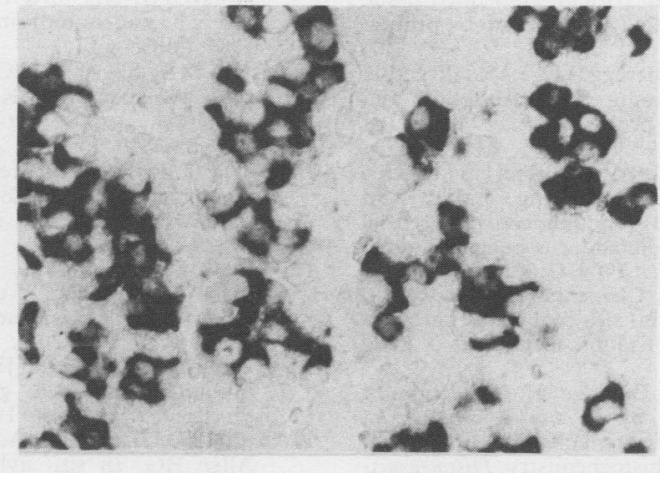

pituitary gland. The specificity of binding is supported by the results of RNAse treatment and blocking studies. In our hands digoxigenin labelling of this probe produced better results than biotin on tissue sections, although studies with other probes (unpublished data) indicate that this is not a constant finding. We found no noticeable difference in signal between paraformaldehyde and neutral buffered formalin fixed tissue, indicating that this technique may usefully be applied to routine histological material.

In addition, labelled probe reacted with a single band of around the correct size for POMC mRNA in Northern blot analysis. Interestingly, biotin labelled probe proved more efficient on blots. The reason for this discrepancy between tissue sections and filters is, at present, unclear.

In the absence of proteinase $K$ treatment signal was seen only in the intermediate lobe, although cellular POMC mRNA concentrations are reported as similar in the two lobes. ${ }^{14}$ Larsson et al also showed this difference and they have suggested that it may reflect different concentrations of proteins in the two groups of cells, masking the sequences in the anterior lobe. ${ }^{11}$ This might be important for the

Figure 5 Dexamethasone causes no subjective change in signal in the intermediate lobe ( $a$ ). There is a noticeable reduction in the anterior lobe ( $b$ ) with only a few corticotrophs giving a weak positive signal (arrows).

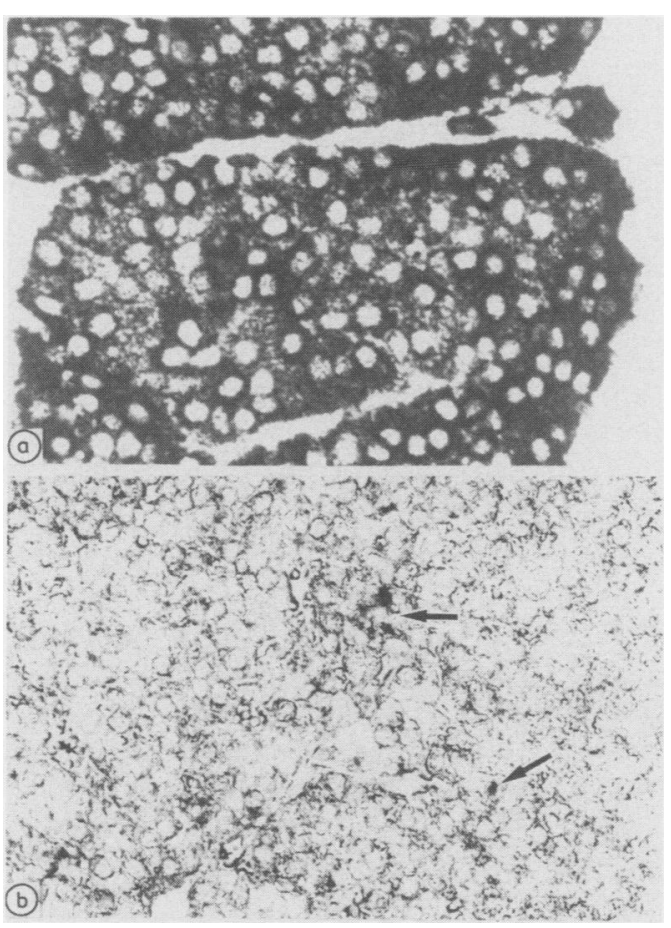

detection of other mRNAs, in that varying concentrations and times of proteinase digestion might be required.

In rats there are two groups of cells which produce POMC, but they are regulated in different ways. The corticotrophs of the anterior pituitary are controlled by hypothalamic stimulating factors and glucocorticoid negative feedback, while the intermediate lobe is regulated by direct dopaminergic innervation. ${ }^{15}$ It is well established that bilateral adrenalectomy ( $\mathrm{Adx}$ ) increases anterior lobe POMC mRNA content, but does not change that of the intermediate lobe. Similarly, the administration of dexamethasone reduces POMC mRNA concentrations in the anterior lobe, but again does not affect the intermediate lobe. ${ }^{16}$ Using the digoxigenin labelled probe, no subjective difference was detected in intermediate lobe signal following either of these experimental procedures but there was an increase in numbers of positive cells in the anterior lobe after removal of adrenals and a reduction induced by dexamethasone. The findings are in keeping with the biochemical data, again indicative of specific binding. At present, quantitative analysis of staining on tissue sections is not possible, but a recent study using radiolabelled probe on dispersed rat pituitary cells suggested that variation in grain density might indicate the mRNA content of the cell. ${ }^{17}$ The subjective changes in intensity of anterior lobe signals following the experimental procedures would be in keeping with this. In addition, the detection of small numbers of positive cells in the treated rats suggests that the technique is sensitive enough to detect very low concentrations of mRNA.

In conclusion, our results indicate that end labelling of oligodeoxynucleotide probes with digoxigenin should prove useful for the detection of specific mRNAs in tissue sections, particularly in organs where concentrations of endogenous biotin are high.

We thank Dr V B Math, University of Glasgow, for synthesising the probe, Mrs J Johnston for typing the manuscript, and Mr T Parker for preparing the photographs.

1 Bloch B, Popovici T, Levin MJ, Tuil D, Khan A. Transferrin gene expression visualized in oligodendrocytes of the rat brain by using in situ hybridization and immunohistochemistry. Proc Natl Acad Sci USA 1985;82: 6706-10.

2 Lloyd RV, Landefeld TD. Detection of prolactin messenger RNA in rat anterior pituitary by in situ hybridization. $\mathrm{Am}$ $J$ Pathol 1986;125:35-44.

3 Cox KH, deLeon DV, Angerer LM, Angerer RC. Detection of mRNAs in sea urchin embryos by in situ hybridization using asymmetric RNA probes. Dev Biol 1984;101: 485-502.

4 Hoefler $\mathrm{H}$, Childers $\mathrm{H}$, Montminy MR, Lechan RM, Goodman RH, Wolfe HJ. In situ hybridization methods for the detection of somatostatin $\mathrm{mRNA}$ in tissue sections using antisense RNA probes. Histochem $J$ 1986;18 597-604.

5 Guitteny A, Fouque B, Mougan C, Teoule R, Bloch B. Histological detection of messenger RNAs with biotinylated synthetic oligonucleotide probes. $J$ Histochem
Cytochem 1988;36:563-71.

6 Pringle JH, Homer CE, Warford A, Kendall CH, Lauder I In situ hybridization: alkaline phosphatase visualization of biotinylated probes in cryostat and paraffin sections. biotinylated probes in cryosta

7 Brigati DJ, Myerson D, Leary JJ, et al. Detection of viral 
genomes in cultured cells and paraftin-embedded tissue sections using biotin labelled hybridization probes. Virology 1983;126:32-50.

8 Dooley S, Radtke J, Blin N, Unteregger G. Rapid detection of DNA-binding factors using protein-blotting and digoxigenin-dUTP marked probes. Nucleic Acids Res 1988;16:11839.

9 Herrington CS, Burns J, Graham AK, Bhatt B, McGee JO'D. Interphase cytogenetics using biotin and digoxigenin labelled probes II: simultang bus detection of human and papilloma virus nucleic acids in individual nuclei. J Clin Pathol 1989;42:601-6.

10 Moench TR, Gendelman HE, Clements JE, Narayan O Griffin DE. Efficiency of in situ hybridization as function of probe size and fixation technique. $J$ Virol Methods 1985;11:119-30.

11 Larsson LI, Christensen T, Dalboge H. Detection of propiomelanocortin mRNA by in situ hybridization using a biotinylated oligodeoxynucleotide probe and avidin-alkaline phosphatase histochemistry. Histochemistry 1988;89:109-16.

12 Burns J, Graham AK, Frank C, Fleming KA, Evans MF, McGee JO'D. Detection of low copy human papilloma virus DNA and mRNA in routine paraffin sections of cervix by non-isotopic in situ hybridization. J Clin Pathol 1987; 40:858-64.

13 Lewis ME, Sherman TG, Burke S, et al. Detection of propiomelanocortin mRNA by in situ hybridization with an oligonucleotide probe. Proc Natl Acad Sci USA 1986;83:5419-23.

14 Civelli O, Birnberg N, Herbert E. Detection and quantitation of proopiomelanocortin mRNA in pituitary and brain tissues from different species. J Biol Chem 1982;257: 6783-7.

15 Tilders FJ, Smelik PG. Direct neural control of MSH secretion in mammals: the involvement of dopaminergic secretion in mammals: the involvement of dopaminergic
tubero-hypophyseal neurons. Frontiers of Hormone tubero-hypophyseal ned
Research 1977;4:80-93.

16 Eberwine JH, Roberts JL. Glucocorticoid regulation of proopiomelanocortin gene transcription in the rat pituitary. J Biol Chem 1984;259:2166-70.

17 Hatfield JM, Daikh DI, Adelman JP, Douglass J, Bond CT Allen RG. In situ hybridisation detection of marked differences in pre-proopiomelanocortin messenger ribonucleic acid content of individual corticotropes and melanotropes. Endocrinology 1989;124:1359-64. 